\title{
Sonographic elbow scanning is not yoga exercise
}

\author{
Kamal Mezian ${ }^{1 *} \mathbb{D}$, Karolína Sobotová ${ }^{2}$ and Yvona Angerová
}

Keywords: Patient positioning, Ultrasound scan, Elbow ultrasonography

\section{Main text}

We have read the manuscript by Abogamal and colleagues with interest [1]. The article describes a comparison of the 90-degree flexion/neutral position of the elbow, sometimes called the "crab" (usually used for the posterior window evaluation) [2], with a standard position. Their results showed a highly significant difference in favor of the 90-degree flexion position. We congratulate the authors for their effort in drawing attention to improve ultrasound elbow scanning ergonomy. Importantly, it has already been reported that repetitive ultrasound examinations may result in musculoskeletal pain in ultrasound practitioners [3]. However, according to our experience, the proposed 90-degree flexion position is not only uncomfortable for the examiner but also for the patient, already presenting with preexisting elbow pain. The position is coupled with internal rotation and extension of the shoulder, and as apparent from the Fig. $3 \mathrm{c}$ also shoulder abduction and an excessive wrist extension. Herewith, this position imposes abnormal pressure on the joints which may cause unnecessary loading of the musculoskeletal system of the patient. Furthermore, the proposed positioning is coupled with a need to change the position to assess the medial and lateral elbow compartments dynamically. In the medial compartment, the examiner may need to perform the dynamic valgus stress test to assess the integrity of the anterior bundle of the medial collateral ligament. On the lateral side, the examiner may need to perform dynamic scanning to evaluate annular ligament and rule out possible occult fractures of the radial head. On the contrary, Mezian and colleagues proposed and published a more ergonomic protocol for all elbow regions examination

\footnotetext{
* Correspondence: kamal.mezian@gmail.com

${ }^{1}$ Department of Rehabilitation Medicine, First Faculty of Medicine, Charles

University, Prague, Czech Republic

Full list of author information is available at the end of the article
}

with the patient lying semisupine on the examination bed [4]. In the future, we suggest a study to compare the semisupine approach to a "standard" protocol [5]. We believe this is of utmost importance for a smooth workflow for musculoskeletal ultrasonographers to prevent chronic injuries and improve the quality of the examination.

\section{Authors' contributions \\ KS, YA and KM have written the manuscript together. The first draft was written by KM. All authors read and approved the final manuscript.}

\section{Funding}

None.

\section{Availability of data and materials}

N/A

Ethics approval and consent to participate N/A

Consent for publication

$\mathrm{N} / \mathrm{A}$

Competing interests

The authors declare that they have no competing interests.

\section{Author details}

${ }^{1}$ Department of Rehabilitation Medicine, First Faculty of Medicine, Charles University, Prague, Czech Republic. ${ }^{2}$ Department of Rehabilitation and Sports Medicine, Second Faculty of Medicine, Charles University and University Hospital Motol, Prague, Czech Republic.

Received: 12 March 2019 Accepted: 19 July 2019

Published online: 29 July 2019

\section{References}

1. Abogamal A, Ghanem S, Saad H. A single simple position for ultrasound assessment of both common extensor and common flexor origin at the elbow. Adv Rheumatol. 2019;59(1):11.

2. Reijnierse M, Kelemouridou M, Miller TT. Video: musculoskeletal ultrasound imaging of the elbow: part 1, Normal anatomy. AJR Am J Roentgenol. 2013; 200(6):W644

3. Claes F, Berger J, Stassijns G. Arm and neck pain in ultrasonographers. Hum Factors. 2015:57:238-45. 
4. Mezian K, Machač S, Zavareh A, Majerníková L, Vacek J, Navrátil L, Schmitz M. Positioning techniques to improve the ultrasound evaluation of the elbow. Ultrasound Q. 2019;35(2):136-41.

5. Özçakar L, Kara M, Chang KV, et al. EURO-MUSCULUS/USPRM basic scanning protocols for elbow. Eur J Phys Rehabil Med. 2015;51:485-9.

\section{Publisher's Note}

Springer Nature remains neutral with regard to jurisdictional claims in published maps and institutional affiliations.

Ready to submit your research? Choose BMC and benefit from:

- fast, convenient online submission

- thorough peer review by experienced researchers in your field

- rapid publication on acceptance

- support for research data, including large and complex data types

- gold Open Access which fosters wider collaboration and increased citations

- maximum visibility for your research: over $100 \mathrm{M}$ website views per year

At $B M C$, research is always in progress.

Learn more biomedcentral.com/submissions 